\title{
Editorial
}

\section{Editorial Introduction: The Global Cultures of Antifascism, 1921-2020}

\author{
Mattie Fitch \\ Department of History and Politics, Marymount University, Arlington, \\ Virginia, USA \\ mfitch@marymount.edu
}

Michael Ortiz

Department of History, University of Northern Colorado, Greeley, Colorado, USA

michael.ortiz@unco.edu

\section{Nick Underwood}

Department of History, The College of Idaho, Caldwell, Idaho, USA nunderwood@collegeofidaho.edu

This special issue of Fascism: Journal of Comparative Fascist Studies is dedicated to David Shneer z"l, to whom we are all indebted and whose scholarship challenged us to consider the ways in which folk-culture could forge antifascist relationships.

Since the origins of antifascism nearly a hundred years ago, antifascist movements have articulated a diverse array of identities, motivations, and allegiances. From the Arditi del Popolo in 1921 to Antifa activists in Portland in 2020 , local cultures have shaped individuals' and groups' understandings of the antifascist phenomenon. Although scholars have traditionally paid less attention to antifascism than fascism, contemporary concerns about protecting democratic societies from exclusionary authoritarian movements have

(C) FITCH, ORTIZ AND UNDERWOOD, $2020 \mid$ DOI:10.1163/22116257-20201199

This is an open access article distributed under the terms of the prevailing CC-BY-NC license at the time of publication. 
(re)kindled scholarly and popular interest. ${ }^{1}$ Much of this scholarship has highlighted antifascism's plurality, or 'its links to widely varying movements and cultures.' 'Anti-fascism,' Hugo García has contended, 'spread in parallel with other transnational movements such as pacifism, anti-colonialism, feminism and anti-capitalism in its various forms. ${ }^{3}$ To date, antifascism's intersections with local, transnational, and global discourses - what we broadly call the 'cultures of antifascism' - remain under-examined. Antifascism adapted to local cultures while retaining its own shared culture - a 'common ground for various strategies, visions and discourses' that included slogans, gestures, and an 'aesthetics of resistance.' ${ }^{4}$ This special issue analyzes the synergistic, and often contested, cultural exchanges that produced, and continue to produce, the panoply of movements, ideologies, and ideas we call 'antifascism' ${ }^{5}$

Building upon the analytical frameworks of Hugo García, Nigel Copsey, Mark Bray, and others, it is the argument of this special issue that examining the messy, debated, and intertwined cultural interactions of antifascism is critical to understanding the larger antifascist phenomena - particularly its political dimensions. In prioritizing cultural approaches, we seek to move beyond traditional narratives of success and/or failure, in order to understand the ways in which particular cultures interpreted (and reinterpreted) antifascist principles. ${ }^{6}$ Whether or not antifascist movements achieved their political goals in the short-term, antifascism often had a long-reaching effect on cultural politics, political coalitions, and civic participation. Investigating how activists conceptualized antifascism reveals the extent to which it intersected with other key allegiances. The authors in this issue expand the definition of antifascism, taking seriously its connections with groups and movements embracing broader agendas. Examining antifascism through a cultural lens can best shed light on these questions, as antifascists used cultural practices to forge

1 Michael Seidman, 'Was the French Popular Front Antifascist?' in Rethinking Antifascism: History, Memory and Politics, 1922 to the Present, ed. Hugo García et al. (New York: Berghahn, 2016), 43. See also Michael Seidman, Transatlantic Antifascisms: From the Spanish Civil War to the End of World War II (Cambridge: Cambridge University Press, 2018).

2 Hugo García, Mercedes Yusta, Xavier Tabet, and Cristina Clímaco, 'Beyond Revisionism: Rethinking Antifascism in the Twenty-First Century,' in Rethinking Antifascism: History, Memory and Politics, 1922 to the Present, ed. Hugo García et al. (New York: Berghahn, 2016), 4.

3 Hugo García, 'Transnational History: A New Paradigm for Anti-Fascist Studies?' Contemporary European History 25, no. 4 (2016): 568.

4 Ibid., 566.

5 Nigel Copsey and Andrzej Olechnowicz, ed., Varieties of Anti-Fascism: Britain in the Inter-War Period (London: Palgrave, 2010).

6 Seidman, 'Was the French Popular Front Antifascist?' 43. 
their positions and identities. Members of antifascist movements understood cultural activities as a crucial aspect of mobilization against fascism, because of the ability of cultural participation to define a group's priorities, develop loyalty to the movement's values, and bring attention to the cause.

The articles presented here explore cultural manifestations of antifascism during the twentieth and twenty-first centuries. They cover a geographic range including China, Australia, and Eastern Europe as well as the traditional focus on Western Europe. ${ }^{7}$ Antifascism, like the fascist advance to which it was a response, was a global phenomenon with important national and local specificities as well as transnational connections. ${ }^{8}$ The scope of this special issue is intentionally broad in order to encompass articles that traverse both the globe and the century that followed the foundation of fascism. Such an approach will allow scholars to better comprehend how culture affected antifascist movements from the early days in Italy to now, and how antifascism has changed over time. It will also illuminate ways antifascism transcended national boundaries or differed in particular national or local contexts. How did war, genocide, and social movements, among other historical forces, influence how antifascists understood and articulated their cultural commitments to fighting fascism wherever it emerged in whatever form?

The articles compiled here are divided regionally, then chronologically. The first two exemplify the cultural approach of the special issue in the 1940s Pacific region. In 'Fighting Fascism with "Verbal Bullets": Kaji Wataru and the Antifascist Struggle in Wartime East Asia,' Edwin Michielsen investigates Japanese antifascist writer Kaji Waturu's wartime production, demonstrating the transnational links activists attempted to forge through cultural means. Though exiled in China, Kaji engaged with Chinese, Japanese, and Korean audiences through his reportage and plays. He worked to foster an anti-imperialist front by focusing on shared experiences of violence and victimization at the hands of fascists and militarists on the battlefield, in Pow camps, and on the home front. Max Kaiser demonstrates how, in the wake

7 Scholarship has too often been restricted to the interwar years and Western nations. Mark Bray and others have emphasized the 'elements of continuity that have existed between interwar and postwar fascism and far-right politics and antifascism (without ignoring the important transformations they have undergone)' as well as 'the historical importance of the anti-fascist resistance of "marginal" groups and communities in recent decades.' Mark Bray, Jessica Namakkal, Giulia Riccò, and Eric Roubinek, 'Editors' Introduction,' Radical History Review, no. 138 (2020): 5, https://doi.org/10.1215/o1636545-8359223. See also Mark Bray, Antifa: The Anti-Fascist Handbook (Brooklyn: Melville House Publishing, 2017).

8 Bray, Namakkal, Riccò, and Roubinek, 'Editors' Introduction,' 3. 
of the Second World War, a distinctive Jewish antifascist politics emerged as a way of memorializing the Holocaust. In "Jewish Culture is Inseparable from the Struggle against Reaction": Forging an Australian Jewish Antifascist Culture in the 1940s,' he examines the ways in which Australian antifascists deployed cultural forms such as painting and writing to forge a Jewish consciousness that contravened fascism and antisemitism. Analyzing the trilingual (Hebrew, Yiddish, and English) magazine Jewish Youth, he contends that Jewish antifascist practice advanced an ambitious program of social critique that simultaneously drew upon transnational political movements while also articulating a transformative vision of both Australian and international culture.

The European continent is the focal point of the next articles, exploring countries and periods not traditionally associated with antifascism or bringing new approaches to bear on established antifascist movements. While antifascism has sometimes been closely aligned with communism, the following two articles help provide a more nuanced understanding of this link. ${ }^{9}$ Ondřej Daniel traces the transformation of the Czech antifascist movement since the fall of communism in Eastern Europe. He argues, in 'Music Subculture vs. Class Revolutionaries: Czech Antifascism in the Postsocialist Era,' that these changes resulted from changing contexts and tactics. The internal dynamics of an antifascist subculture with links to anarchism drove a shift from a focus on anti-capitalism and physical confrontations with far-right skinheads to a prioritization of lifestyle choices, cultural events such as May Day music festivals, and anti-totalitarianism, rejecting communism along with fascism. Instead, street tactics such as antifascist blockades have been increasingly adopted by broader groups with no particular political affiliation who seek to directly oppose neo-Nazi marches. Meanwhile, Zoé Grumberg elucidates the complicated relationship between communism and antisemitism after the Second World War in France. Her article, "L'antisémitisme est l'auxiliaire obligatoire du fascism": Jewish communists, antifascism and antisemitism (France, 1944-196os)' demonstrates how Jewish communists fought against antisemitism as both antifascists and resistance fighters. Grumberg shows how many idolized the Soviet Union as the state that had defeated fascism and eradicated antisemitism. However, as Soviet antisemitism increased during the 195os, French communists confronted a crisis of identity. Grumberg's examination of the complex intersections between Jewish identity and the culture of French communist politics demonstrates why many Jewish communists could not bring themselves to condemn Soviet antisemitism and followed French

9 García, Yusta, Tabet, and Clímaco, 'Beyond Revisionism, 3. 
Communist Party doctrine denying any such accusations. Grumberg therefore deconstructs the ways in which these actors 'could condemn what resembled a Nazi antisemitism, but chose to ignore what we could call an "antifascist antisemitism".' Louie Valencia expands on the importance of intersectionality for an appreciation of antifascism in his examination of late Francoist Spain's distinct antifascist culture, 'Pluralism at the Twilight of Franco's Spain: Antifascist and Intersectional Practice.' During the 1970s, Spanish fascism deployed a dizzying array of anti-pluralist social categories (both real and imagined), tormenting vulnerable and marginalized communities. Valencia analyzes the ways in which Spanish antifascist culture developed and articulated pluralist practices in order to challenge these divisions. In resisting the marginalization of the Francoist state, Spanish antifascists deconstructed categories such as class, ethnicity, gender, race, nation, class, religion, sexuality, and embodiment.

Like Grumberg and Valencia, Joshua Cohen adds to our picture of the ways that antifascism facilitated an interplay between specific experiences and identities and broader commitments or movements in "Somehow Getting Their Own Back on Hitler": British Antifascism and the Holocaust, 196o-67.' Cohen views the 1960 os in Britain as a transitional period in which antifascists increasingly invoked the memory of the Holocaust to create links to anti-racist movements. He finds that while some Jewish groups employed references to the Holocaust as political capital for forming antifascist and anti-racist political coalitions, Jewish organizations disagreed about the contemporary implications of the genocide. Even as the Holocaust resonated more broadly in these years as the consummation of extreme racism, its invocation could also mean downplaying specific Jewish experiences. Iker Itoiz Ciáurriz illuminates a similarly transitional moment in the history of British antifascism two decades later, and along with it the evolving relevance of antifascism in multiple contexts. In 'Looking for a Dream, Surviving a Time of Nightmares: Eric Hobsbawm, Marxism Today and the Resignification of Antifascism During Thatcher's Time,' he argues that Marxist historian Eric Hobsbawm reframed antifascism in 1980s Britain, invoking his memories of the French Popular Front and the interwar antifascist movement to imbue the fight against Thatcher and neoliberalism with meaning. Though he did not view Thatcher as another Hitler, he presented the threat of Thatcherism as similar to that of fascism in the 1930s, in that it undermined workers' rights. To meet this threat, he relied on the emotional power of his personal experiences and those of many of his readers to propose antifascism as a unifying force within a fragmented left that could renew the Labour movement.

Three articles on antifascism within the German context explore the complex negotiations that occurred between antifascism and other identities 
through cultural means, showing that being a woman, an athlete, or a Jewish refugee could complicate, offset, or strengthen antifascist commitment. Sara Sewell's 'Antifascism in the Neighborhood: Daily Life, Political Culture, and Gender Politics in the German Communist Antifascist Movement, 1930-1933' examines how gender relations shaped the culture of leftist resistance to Nazism. In the final years of the Weimar Republic, as Nazis and communists (principally, the KPD) competed to adorn Germany with their emblems, daily conflict often took on a political dimension. Few, if any, could escape this 'politicization of the ordinary' - particularly women. Sewell contends that while women were often at the center of KPD activism - engaging in propaganda work, electioneering, demonstrations, and physical struggle - they frequently confronted widespread discrimination from their male comrades. Using the writings of rank-and-file communists as well as sympathizers, Sewell contrasts KPD efforts at cultivating a proletarian resistance with a culture of hypermasculinity that ultimately blocked women from the frontlines of struggle. If gender proved a barrier for women activists, dedication to a sport could allow athletes to transcend fraught political divisions. The 1936 Berlin Olympics are often depicted as a triumph of German propaganda or an archetype of athletic antifascist resistance. In Olympia, for example, Leni Riefenstahl presented idealized Aryan athletes competing against their democratic counterparts most famously, Jesse Owens. In 'Antifascist Athletes? A Reappraisal of the ${ }_{1936} 6$ Berlin Olympics,' Keith Rathbone challenges this Manichean — often teleological - portrayal of the Berlin Olympics. Analyzing international boycott movements as well as the experiences of individual participants, he contends that many of the athletes at the Berlin Olympics ignored the political ramifications of their participation. Privileging the experiences of the athletes, Rathbone calls for understanding the games as a cultural form of resistance to politicization - one that moves beyond the limited dichotomy of fascist and antifascist. While gender complicated antifascist engagement within Germany, for German Jewish exiles Germanness and antifascism were at first mutually reinforcing. After the rise of Nazi Germany, thousands of Germans fled persecution from the Third Reich. The historiography of exile communities has largely been divided into two distinct groups: Jewish refugees and political emigrants. In 'Exile Dreams: Antifascist Jews, Antisemitism and the "Other Germany", Anna Koch examines the individuals who intersected these categories. German Jewish antifascists were persecuted for their politics as well as their common ethnic ancestry. At the same time, Koch argues, these dual identities fostered a culture of belonging that enabled them to hold onto their Germanness and hope to return to a different Germany. Even after the Second 
World War, when many antifascist Jews became disillusioned with the idea of an 'other Germany', they remained attached to the culture of antifascism.

The last two articles take us beyond national boundaries while picking up many of the themes addressed in the previous contributions. In 'Tales of Antifascism: International Survivors' Organizations in the 195os,' Maximilian Becker argues that members of international survivors' organizations interpreted their political activities through their memories of resisting fascism. On the one hand, groups on opposite sides of the Cold War relied on multiple and evolving understandings of antifascism, which caused them to develop different meanings of some key words depending on their relationship to communism. Despite Cold War divisions, on the other hand, Becker finds significant overlap in the memories of communist and non-communist organizations. Groups employed cultural methods to create and promote a common cross-border memory that emphasized heroism and unity and sometimes conditioned similar political engagements, such as opposition to West German rearmament. Victor Lundberg's piece, "The Antifascist Kick": A Signifying Cultural Practice in the History of Transnational Antifascism?' takes us into the twenty-first century. Lundberg investigates 'the antifascist kick' as a cultural practice and political symbol that illuminates the transnational and evolving nature of antifascism in contexts as diverse as Sweden in 1934, Germany in the 199os, and the United States in 2017. Given the centrality of violence to fascism, antifascist violence has been a point of debate among activists. Lundberg analyzes the iconic kick as real and imagined violence employed by antifascist activists against the fascist threat. The kick, he argues, encouraged ongoing antifascist engagement while also defining leftwing morality, promoting group unity, legitimizing violence, dehumanizing fascists, and sometimes celebrating aggressive masculinity.

These articles challenge us to rethink antifascism in a way that takes seriously the cultural and grassroots foundations of these movements. As a whole, they exhibit the cultural particularity and interconnectedness of antifascist ideologies that have been key, though underappreciated features since the beginning. Giving special emphasis to the ways in which antifascism evolved with and adapted to various cultures, these articles illuminate why antifascism in its multitude of forms has resonated across the years and the globe, and continues to do so today. 